\title{
TECCIENCIA
}

\section{Development of automation and control system for the freezing of bovine semen}

\section{Desarrollo de sistema de automatización y control para el congelamiento de semen bovino}

\author{
Jhon E. Arango $\mathrm{T}^{1 *}$, Cristhian M. Duran ${ }^{1}$, Jhon E. Lizarazo ${ }^{2}$, Jorge A. Duarte ${ }^{3}$ \\ ${ }^{1}$ Grupo de investigación GISM, Facultad de Ingenierías y Arquitecturas, Universidad de Pamplona. Pamplona, Colombia. \\ ${ }^{2}$ SENA, electrónica y telecomunicaciones, Tecnoparque, Ocaña, Colombia. \\ ${ }^{3}$ SENA, Biotecnología, Centro Agroempresarial, Aguachica, Colombia.
}

Received:

Accepted:

Available Online:

\begin{abstract}
The freezing of bovine semen (cryopreservation) consists in reducing the temperature of the sample until the point of biological stability. This freezing process is carried out by immersing the semen samples into liquid nitrogen (LN2). When a sample is submerged, it enters into a boiling regime due to the large difference in temperatures between the sample and the liquid nitrogen (LN2), causing evaporation and crystallization. Freezing curves for biological samples of bovine semen are rarely found in scientific literature; however, there are several rhythms of freezing that have been manually carried out and have achieved acceptable results. The main objective of this study is to design and implement an automated control system of freezing bovine semen that can follow or simulate the ideal freezing curves for optimal freezing after stabilization.
\end{abstract}

Keywords: Cryopreservation, liquid nitrogen (LN2), freezing curves.

\section{Resumen}

El congelamiento de semen bovino (criopreservanción) consiste en reducir la temperatura de las muestras seminales hasta el punto de estabilidad biológica. Este proceso de congelamiento se lleva acabo sumergiendo las muestras de semen en nitrógeno líquido (LN2). Cuando la muestra es sumergida, entra en un régimen de ebullición debido a la gran diferencia de temperatura entre la muestra y el nitrógeno líquido (LN2), causando evaporización y cristalización. Las curvas de congelamiento de muestras biológicas de semen bovino no son comunes en la literatura; sin embargo existen referencias que describen varios ritmos de congelamiento que se han realizado experimentalmente y han alcanzado resultados aceptables. El objetivo de este estudio es desarrollar un sistema automatizado de control para el congelamiento de semen bovino que pueda seguir o simular las curvas de congelamiento para una congelación optima después de la estabilización.

Palabras clave: Criopreservanción, nitrógeno líquido (LN2), Curvas de congelamiento.

\section{Introduction}

The cattle sector in Colombia occupies a place of great importance in relation to the economic development of some regions of the country, so special attention is required to

*Corresponding Author.

E-mail: elier_arango@misena.edu.co maintain and increase the bovine population with the appropriate technology that can be implemented in a way that is accessible and efficient in the field of reproduction [1].

How to cite: Arango, T. Jhon E., Duran, Cristhian M.,Lizarazo, Jhon E., Duarte, Jorge A., Development of automation and control system for the freezing of bovine semen, TECCIENCIA, Vol. 12 No. 23., 69-74, 2016,

DOI: $\underline{\text { http://dx.doi.org/10.18180/tecciencia.2017.23.8 }}$ 


\section{TECCIENCIA}

The present project aims to provide an important contribution in the automation and control of the freezing procedure of bovine semen; with the objective of using the available technology which is based on research where the optimum freezing rates and adaptations of cooling curves of bovine semen have been determined.

Bovine semen can be preserved using experimental freezing systems that use exposure to liquid nitrogen gases or through programmable automated freezing systems that can follow a certain pre-programmed rate of freezing. Most of the published works in relation to cryo-preservation [2] [3] [4] [5] [6] use programmable automated freezing systems that use different freezing rates (thermal descent velocity) as described below:

The descent speed of $5^{\circ} \mathrm{C} / \mathrm{min}$ is applied within temperatures of $5^{\circ} \mathrm{C}$ to $-10^{\circ} \mathrm{C}$, then $40^{\circ} \mathrm{C} / \mathrm{min}$ is applied within temperatures from $-10^{\circ} \mathrm{C}$ to $-100^{\circ} \mathrm{C}$, and lastly a speed of $20^{\circ} \mathrm{C} / \mathrm{min}$ is applied from $-100^{\circ} \mathrm{C}$ to $-140^{\circ} \mathrm{C}$, as illustrated in Figure 1.

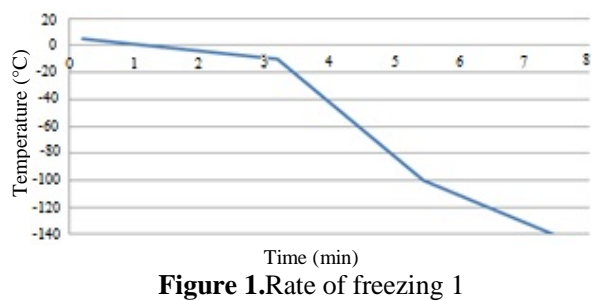

In addition to the freezing rate mentioned above in Figure 1, other freezing rates can be found in different studies by other authors [2] [3] [4] [5] [6]. Among these alternative rates is, for example, a rate of $5^{\circ} \mathrm{C} / \mathrm{min}$ between $+5^{\circ} \mathrm{C}$ and $-10^{\circ} \mathrm{C}$, and $40^{\circ} \mathrm{C} / \mathrm{min}$ between $-10^{\circ} \mathrm{C}$ and $-150^{\circ} \mathrm{C}$, as shown in Figure 2 , and a faster freezing rate of $60^{\circ} \mathrm{C} / \mathrm{min}$ between $+5^{\circ} \mathrm{C}$ and $120^{\circ} \mathrm{C}$ as shown in Figure 3 [6].

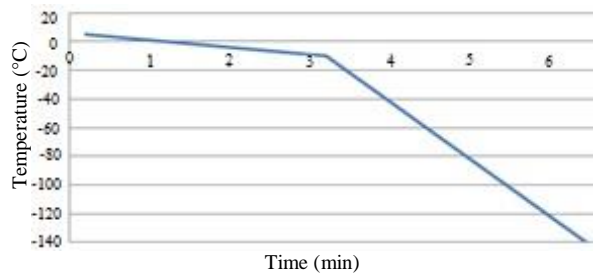

Figure 2.Rate of freezing 2

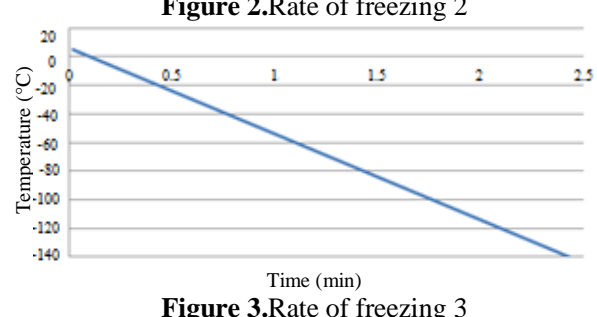

Figure 3.Rate of freezing 3

Regarding freezing in static nitrogen vapors, many institutions and individuals still use this method even though this process has considerable disadvantages, since samples containing semen are exposed to uncontrollable freezing conditions

If the freezing process is carried out by exposure to liquid nitrogen gases, the freezing temperature depends on the vertical distance (height) to the level of coolant (liquid nitrogen) at which the straws (where the seminal samples are deposited) are located. For this experimental freezing process, the temperature falls at a rate ranging from $150^{\circ} \mathrm{C} / \mathrm{min}$ to $300^{\circ} \mathrm{C} / \mathrm{min}$. Also recommended is a freezing rate of exposure of the straws to $-150^{\circ} \mathrm{C}$ in a maximum time of $7 \mathrm{~min}$. These seminal parameters represent a good postthawing behavior [6].

Freezing the seminal samples by exposure to liquid nitrogen gases has the advantage of allowing the user to be able to control the freezing process at all times by subjecting the sample to the same rate of thermal descent (cooling) at all times during the freezing process, due to the fact that the samples are located at the same height. On the other hand, in programmable automated freezing systems the samples are located at different levels, contributing to imposing variations in the freezing rate [6] y [7].

When freezing using the exposure to liquid nitrogen gases method, in most cases, the sample cases used are made of expanded polystyrene (EPS).

In this freezing procedure the straws are exposed for a time no greater than $15 \mathrm{~min}$ (where $10 \mathrm{~min}$ is recommended) [8], generally located $4 \mathrm{~cm}$ above the level of the liquid refrigerant (liquid nitrogen) [2]. The freezing rate is usually $60^{\circ} \mathrm{C} / \mathrm{min}$, depending exclusively on the height between the straws and the level of liquid nitrogen. Investigations by other authors [6] found no major differences in the postthawing process in motile seminal samples using different heights on the surface of liquid nitrogen.

In relation to the separation distance between the straws, the surface of the liquid nitrogen and the time of exposure, there are some differences between authors that are found in the literature. With respect to these differences, authors Tuli and Holtz in 1992, which is cited by Hidalgo in 2004 [6], observe better results in sperm quality when the seminal samples are placed at a height of $2 \mathrm{~cm}$ from the surface of the liquid nitrogen for a period of time that oscillates between 8-9 min. For author Vazquez in 1998, when freezing through exposure to liquid nitrogen gases, the seminal samples should remain exposed for a time of $10 \mathrm{~min}$ [6] [8].

The current methods of freezing bovine semen in the region (departments of Cesar, Norte de Santander and Bolívar, Colombia) are invasive. This can result in many of the samples being defective and that the loss rate is very large. Due to this reason, new ways to replace this method by using a non-invasive automated system in which the freezing 


\section{TECCIENCLA}

process is performed completely in a chamber without the need for human intervention that could contaminate the samples is the ideal solution.

This project seeks to take advantage of electronic systems, automation and control to improve the process of freezing bovine semen. This improvement will result in a better quality of the semen, resulting in a higher pregnancy rate and thus allowing a greater number of straws to be frozen while taking advantage of the limited amounts of liquid nitrogen, which is the freezing agent and preservative

The implementation of automation and control methods offers the industrial sector the alternative of offering better quality products by optimizing the resources used in the processes [9], [10] y [11] reducing occupational and environmental risks, achieving greater harmony between the products, the environment and the personnel that works, all of which can be important aspects that can be achieved by this proposal.

The Figure 4 describes the process that is going to be automated; the freezing process of bovine semen can be seen in a flowchart

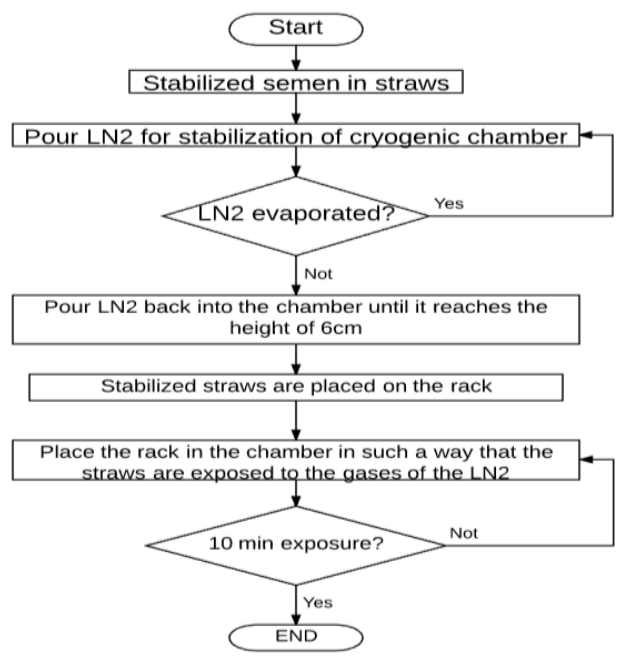

Figure 4. Current procedure used to freeze bovine semen.

\section{Materials and methods}

\subsection{Materials}

Figure 5 shows a Piping and Instrumentation Diagram/Drawing (P\&ID) diagram which is a piping and instrumentation diagram describing the hardware of the implemented system. This system consists of a compressor that provides a maximum of $100 \mathrm{psi}$, an air handling unit composed of a $3 / 2$ valve, a filter, a regulator and a manometer, a digital programmable pressure switch with digital output and analog output, in order of measuring the circulating pressure, a proportional controlled pneumatic solenoid valve controlled by an integral proportional controller and regulating the flow of air from the compressor, a liquid nitrogen storage tank (LN2) with a capacity of 20 liters which has a plug that was made with three holes for the intake of air from the solenoid valve and a nitrogen gas outlet and for the exhaust valve as described in Figure 6.

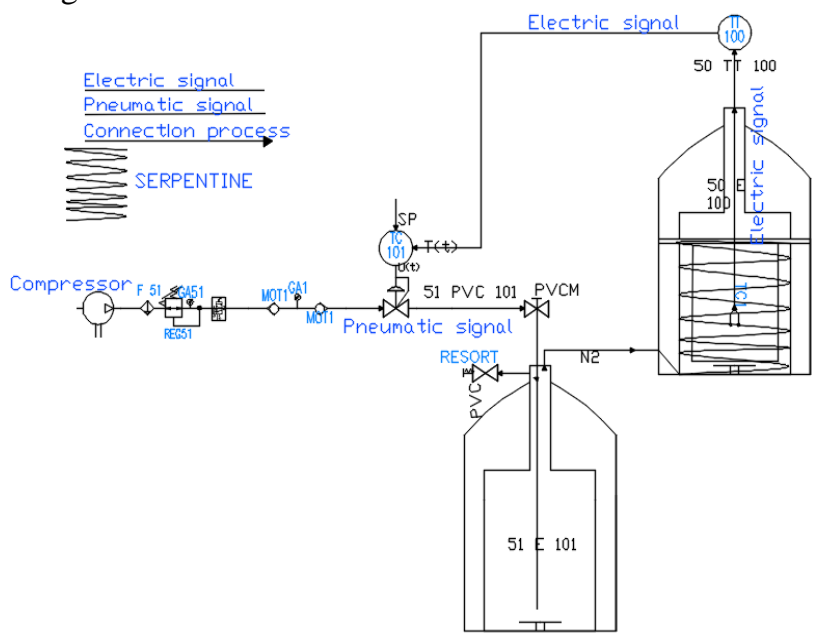

Figure 5.P\&DI diagram of the system

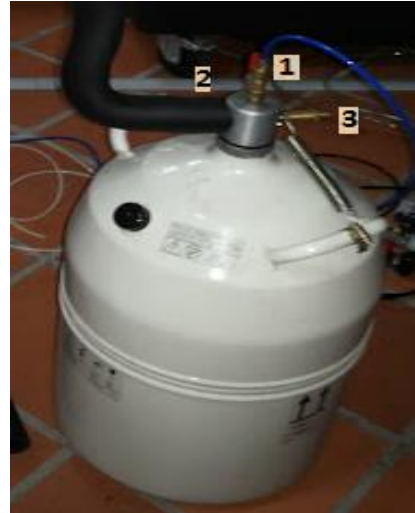

Figure 6.Storage tank of LN2 and its respective valve 1) air intake, 2) nitrogen gas exit, 3) escape valve.

This tank was adapted to the process and internally contains a coil for uniform temperature distribution (See Figure 7).

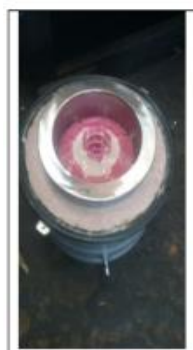

a)

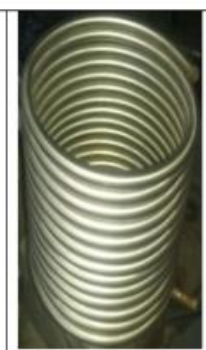

b)

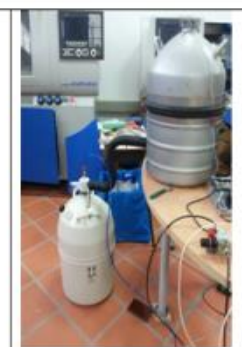

c) 


\section{TECCIENCIA}

Figure 7.a) Cryogenic chamber of customed tank, b) Coil for uniform distribution of temperature, c) Tanks coupled together ready for tests.

National Instruments data acquisition cards were used for the acquisition of temperature and pressure data, which was coupled to the labView software. This card is highperformance and was also used to carry out the control output. The acquired data were stored for further analysis and design of the PI controller that controls the solenoid valve. In Figure 8 we can see the hardware data acquisition and control output system and the functional assembly of the freezing system.

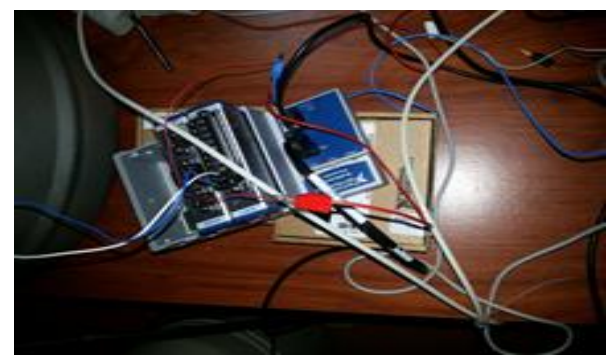

a)

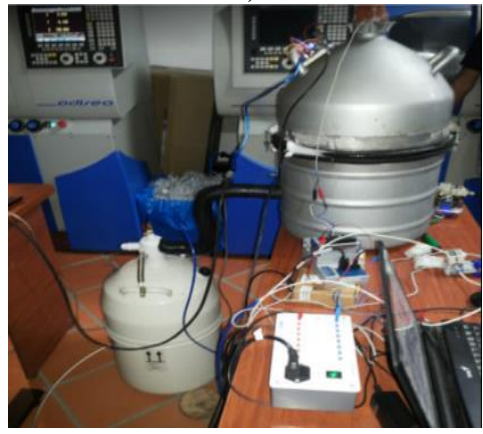

b)

Figure 8.a) Output control and acquisition hardware system b) Freezing system.

One of the main contributions to the research was the development of an innovative $2 \mathrm{~cm}$ diameter circular straw holder that fits the cryogenic chamber and covers a maximum of $0.5 \mathrm{ml}$ straws (see Figure 9). This rack has a maximum capacity of 1028 straws distributed in 13 independent and modular rings distributed from the outside to the inside (see Table 1).

Table 1 Straw-holder distribution

\begin{tabular}{|l|l|}
\hline \multicolumn{1}{|c|}{ Diameter $(\mathbf{c m})$} & \multicolumn{1}{c|}{$\mathbf{N}^{\circ}$ Straws } \\
\hline $20,19,18$ & 116 Each module \\
\hline $16.5,16,14,13$ & $96,96,88$ y 80 \\
\hline $12,11,10,9.5,8.5,7.3$ & $76,72,56,44,40,36$ \\
\hline
\end{tabular}

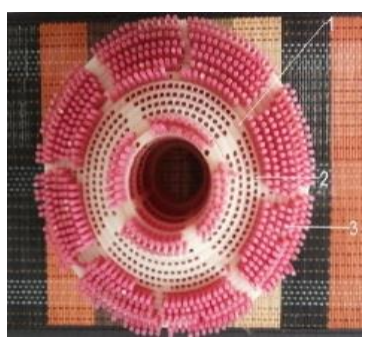

a)

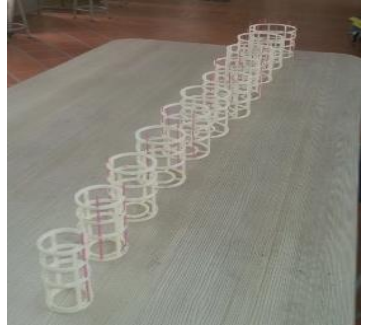

b)
Figure 9.a) View of the rack b) Modules

\subsection{Methodology}

Figure 10 shows an experimental identification process (graphic method) [12], which shows a flowchart describing the procedure to follow (Previous system knowledge, experiment data logging, data treatment, data, model calculation and validation of the model). The process consists in taking the system to a point of operation to then apply a different input and acquire the tabulated data. This data acquisition was done in an open loop [11] [12] [13]. The manipulated variable or input variable is the airflow from the compressor to the $\mathrm{LN}_{2}$ liquid nitrogen tank and the controlled or variable output is the temperature.

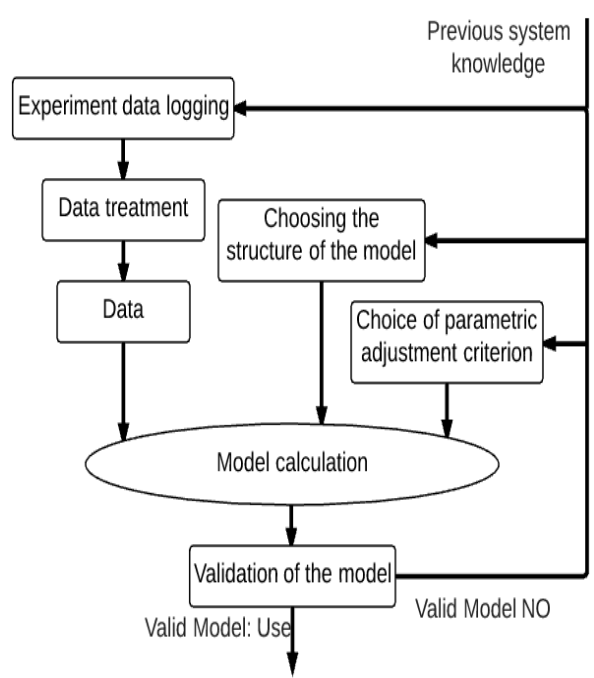

For the experiment the maximum pressure that the liquid nitrogen storage tank, which is, according to the experimental tests of 75 psi and that was the maximum pressure with which it was experimented, was taken into account. This information served to define that when the Solenoid valve was $100 \%$ open the system was subjected to a pressure of $66 \mathrm{psi}$ and thus avoid accidents.

Considering that 66-psi depicts the maximum value accepted by the tank $(100 \%)$, the following rate of input pressure staging was initially applied with a pressure of 33 psi, which represents the $50 \%$ opening of the solenoid valve 


\section{TECCIENCIA}

for a time period of $20 \mathrm{~min}$. After this time, the pressure was increased to $45 \mathrm{psi}$, which equates to $70 \%$ of the opening of the solenoid valve for $10 \mathrm{~min}$. After this time the inlet pressure was regulated again at $33 \mathrm{psi}$ for a time of $10 \mathrm{~min}$, reducing it to $20 \mathrm{psi}$, equivalent to $30 \%$ of the opening of the solenoid valve for a time of $10 \mathrm{~min}$, where finally a pressure was established of $45 \mathrm{psi}$ for a time of $10 \mathrm{~min}$ (See Figure 11).

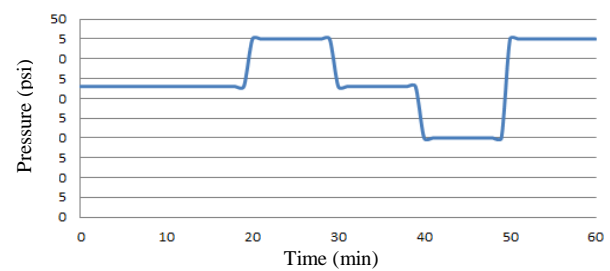

Figure 11. Rates of input pressure scaling

The data (psi pressure vs. Temperature ${ }^{\circ} \mathrm{C}$ ) were acquired through the data acquisition card and the behavior of the system was monitored through the labView software [14] [15] [16] [28]. The obtained data was stored for later analysis, applying these stepping rates, which resulted in a downward temperature curve that reached up to $-100^{\circ} \mathrm{C}$.

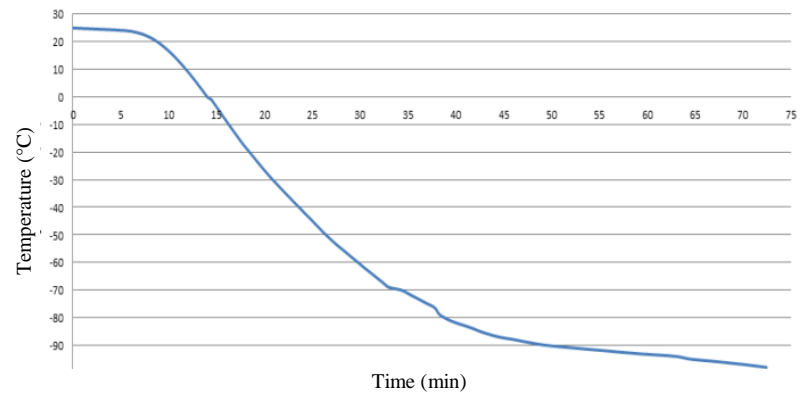

Figure 12.Response to the scaling rates of the input pressure

The collected data was analyzed with the ident tool of MATLAB where it was possible to identify the transfer function of the plant in terms of the first order frequency, resulting in (1):

$$
G(s)=\frac{E(s)}{I(s)}=\frac{-0.02732}{s+0.0002303}
$$

By means of (1) the controller parameters were calculated using the Turing PID tool of Matlab.

First the system response was simulated before a step signal for a P-type controller, giving a response time $\mathrm{Tr}$ of $3140 \mathrm{~s}$ equivalent to $52 \mathrm{~min}$, a Ts stability time of $5580 \mathrm{~s}$ equivalent to $93 \mathrm{~min}$ seen in the Figure 13 and the proportionality constant $\mathrm{Kp}=-0.017216$.

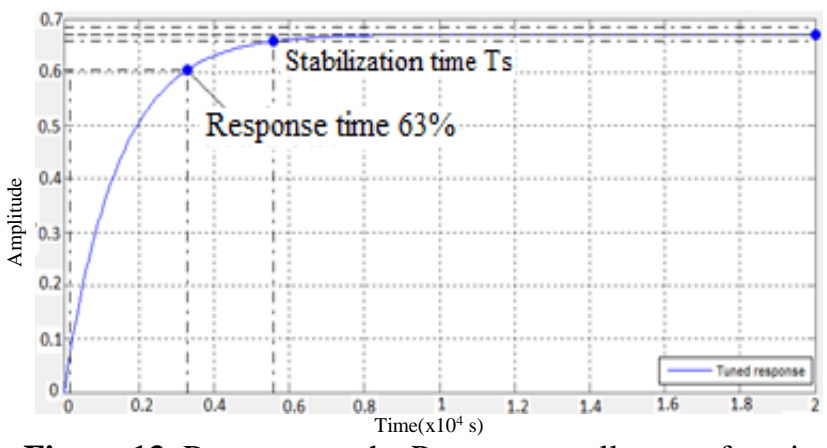

Figure 13. Response to the P-type controller step function

Figure 13 shows that the signal never reaches 1, which would be the desired value.

The simulation of the system response to the step function for the PI controller whose calculated values of constants $\mathrm{K}_{\mathrm{p}}=-0.0087863$ and $\mathrm{K}_{\mathrm{i}}=-6.0718 \mathrm{e}-06$ were obtained in response to a response time $\operatorname{Tr}$ of 3510 s equivalent to 58.5min, see Figure 14.

The $\mathrm{K}_{\mathrm{p}}$ and $\mathrm{K}_{\mathrm{i}}$ values for the PI controller were implemented in the PID block of the LabView software and a response time of $4880 \mathrm{~s}$ ( $81 \mathrm{~min}$ ) was obtained for a temperature range which went from room temperature to $-120^{\circ} \mathrm{C}$ final temperature of the freezing process. These times can be improved by varying the values of the PI controller constants [10] [17] [18] [19] [20].

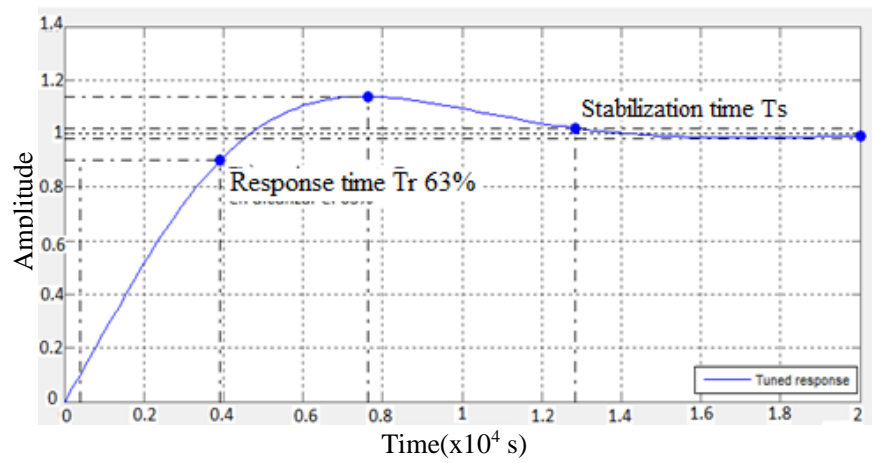

Figure 14. Response to the step controller function of the PI controller.

\section{Results and Discussion}

\subsection{Results}

The directly proportional relationship between the manipulated variable (airflow pressure) and the controlled variable (temperature) was observed and is shown in Table 2 below, where the system was subjected to a $50 \%$ opening of the solenoid valve 33 psi. 


\section{TECCIENCIA}

Table 2 Output temperature data $\left({ }^{\circ} \mathrm{C}\right)$ at an input of a 33 (psi) to the response times in $(\mathrm{min})$

\begin{tabular}{|c|c|c|c|}
\hline $\begin{array}{c}\text { Temperature } \\
\left({ }^{\circ} \mathbf{C}\right)\end{array}$ & $\begin{array}{c}\text { Seconds } \\
(\mathbf{s})\end{array}$ & $\begin{array}{c}\text { Minute } \\
(\mathbf{m i n})\end{array}$ & $\begin{array}{c}\text { Time } \\
\text { difference } \\
(\mathbf{m i n})\end{array}$ \\
\hline 25 & 0 & 0 & 0 \\
\hline 24 & 334.565 & 5.57608333 & 5.57608333 \\
\hline 14 & 646.646 & 10.7774333 & 0.27976667 \\
\hline 4 & 790.174 & 13.1695667 & 0.21945 \\
\hline-6 & 928.62 & 15.477 & 0.20276667 \\
\hline-18 & 1077.538 & 17.9589667 & 0.22843333 \\
\hline-19 & 1092.014 & 18.2002333 & 0.24126667 \\
\hline-20 & 1106.028 & 18.4338 & 0.23356667 \\
\hline-21 & 1120.273 & 18.6712167 & 0.23741667 \\
\hline-22 & 1134.672 & 18.9112 & 0.23998333 \\
\hline-23 & 1148.147 & 19.1357833 & 0.22458333 \\
\hline-24 & 1162.469 & 19.3744833 & 0.2387 \\
\hline-25 & 1176.56 & 19.6093333 & 0.23485 \\
\hline-26 & 1191.19 & 19.8531667 & 0.24383333 \\
\hline-27 & 1205.743 & 20.0957167 & 0.24255 \\
\hline & & & \\
\hline
\end{tabular}

As can be seen in Table 2 and shown in Figure 15, the times between each degree are shortened as the execution time elapses, obtaining an average of $0.38645609 \mathrm{~min}$, the duration to run from $25^{\circ} \mathrm{C}$ to $-120^{\circ} \mathrm{C}$ were close to $60 \mathrm{~min}$.

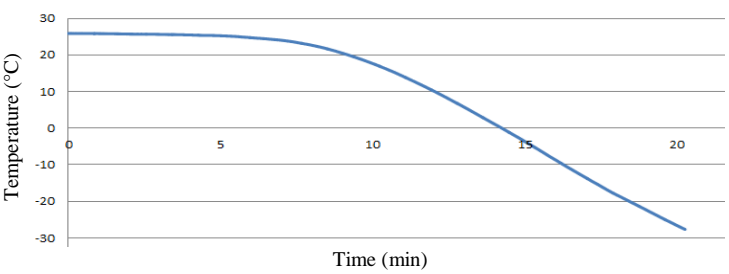

Figure 15. Rate of freezing at $33 \mathrm{psi}$

Finally, with a $100 \%$ solenoid valve opening (at 66 psi) the data shown in Table 3 and Figure 16 were obtained

Table 3 Output temperature data $\left({ }^{\circ} \mathrm{C}\right)$ at an input of at 66 (psi) with response times in ( $\mathrm{min}$ )

\begin{tabular}{|c|c|}
\hline Difference (min) & Temperature ${ }^{\circ} \mathbf{C}$ \\
\hline 0.11036667 & 5 \\
\hline 0.09564465 & -6 \\
\hline 0.11264815 & -17 \\
\hline 0.10952007 & -38 \\
\hline 0.10459167 & -49 \\
\hline 0.09988208 & -60 \\
\hline 0.102025 & -71 \\
\hline 0.10351415 & -82 \\
\hline 0.12262963 & -93 \\
\hline 0.09564465 & -104 \\
\hline 0.11336111 & -115 \\
\hline 0.09322327 & -116 \\
\hline 0.1078 & -117 \\
\hline 0.22441536 & -118 \\
\hline 0.11478704 & -119 \\
\hline 0.09867138 & -120 \\
\hline
\end{tabular}

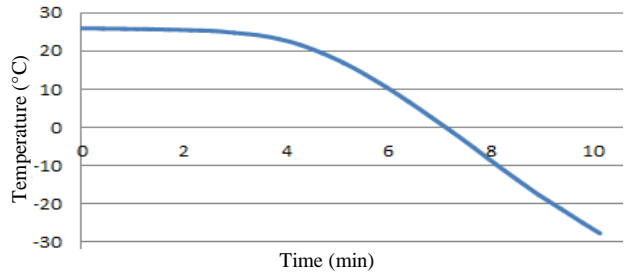

Figure 16. Freeze rate at 66 psi

Table 3 and Figure 16 show that the times are cut in half from those of Table 2 and Figure 15.

With this freezing process, a softer downward temperature change is guaranteed, complying with the times stipulated in previous studies [21] [22] where times between 10 and 15 min are recommended, which causes the thermal shock (osmotic stress) to have a smaller impact on each of the spermatozoa, producing a semen of better quality.

With the developed freezing system, the use of liquid nitrogen was considerably improved, since the process could be carried out with an amount ranging from 5 to 6 liters for the freezing process, which involves the thermal stabilization of the cryogenic chamber (going from room temperature to $5^{\circ} \mathrm{C}$ ) [23] [24] and the freezing process itself (from $5^{\circ} \mathrm{C}$ to $-120^{\circ} \mathrm{C}$ ). While with the traditional method used in the region (Figure 4), 6 liters are needed to temper the vat where the process is carried out.

The system was compared with other efficient and low cost methodologies having equally good results and adaptable to other cold curves for different livestock species.

\subsection{Discussion}

There are currently bovine semen freezers manufactured in leading European countries such as France (Digicool IMV Freezer), its accessibility is very low, since it only has presence in countries like France, the USA, China, the Netherlands, India and Italy [25], Figure 17. In Germany, the animal reproduction company (Minitube), offers a market freezer, TurboFreezer (Figure 18, smaller version) where the price is very high, around 100,000 dollars and they are bulky. Minitube is a company that has representation in countries such as Germany, USA, Spain, Chile, Brazil, Austria, China, India and Central Europe as reported in [26].

In the United States and Australia, the portable freeze control freezer, Freeze Control, models CL-2200, CL-3300, CL-5500, CL8800 are built by labBiogenics, Napa, California, USA. Cryologic, Mulgrave, Australia, which requires the addition of liquid nitrogen and only freezes a maximum of 23 straws of $0.5 \mathrm{ml}$ taking into account that the models that control temperatures from $40^{\circ} \mathrm{C}$ to $-120^{\circ} \mathrm{C}$ are the CL-3300 and CL-8800, seen in Figure 19 [27]. 


\section{TECCIENCLA}

In South America, Brazil is launching itself as one of the powers in applied research regarding the development of bovine semen freezers. In this country, the Cryogen HSE Portable Semen and Embryo Comaogen HSE Portable Freezer was developed with the capacity for 300 straws of $0.5 \mathrm{ml}$ and 600 of $0.25 \mathrm{ml}$ and has distributors of its products in Colombia (Figure 20).

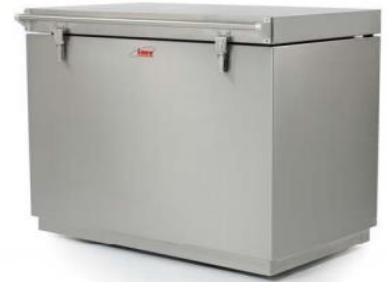

Figure 17.Computerized automated Digicool IMV freezer

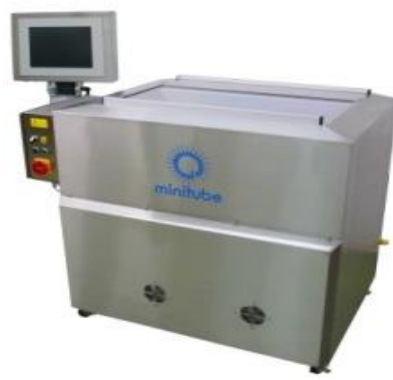

Figure 18.Minitube TurboFreezer Freezer

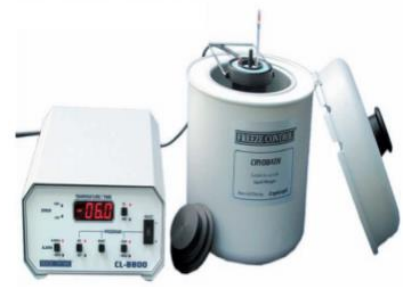

Figure 19.Frezze control CL8800 System

Table 4 shows the most important characteristics of several common freezers on the market

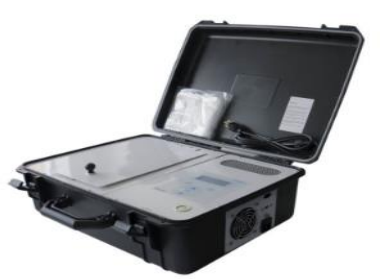

Figure 20.CRYOGEN HSE Portable automated semen and embryo freezer

The TurboFreezer freezers from Minitube and MicroDigicool IMV does not have accessibility in Colombia because the frequency of the network it works is $50 \mathrm{~Hz}$ and in Colombia, the power grid works at $60 \mathrm{~Hz}$ [25] [26]. Even though there are commercial converters that convert frequencies from $50 \mathrm{~Hz}$ to $60 \mathrm{~Hz}$ and vice versa, they are expensive and the final installation would be affected from the financial point of view. MT Freezer 2.0 freezers from Minitube have no problem with power but are bulky and cannot be considered portable.

Freeze control, model CL-8800 is accessible and portable, however, the Table 4 illustrate the straw capacity is very small compared to other freezers.

Table 4 Freezer Characteristics

\begin{tabular}{|c|c|c|c|c|}
\hline Freezer & $\begin{array}{c}\mathrm{N}^{\circ} \text { of } \\
\text { straws } \\
0.5 \mathrm{ml}\end{array}$ & $\begin{array}{l}\text { Quantit } \\
\text { y LN2 } \\
\text { (L) }\end{array}$ & Size & $\begin{array}{l}\text { Power } \\
\text { supply }\end{array}$ \\
\hline $\begin{array}{c}\text { Minitube } \\
\text { TurboFreeze } \\
\text { r }\end{array}$ & 1500 & 8,5 & $\begin{array}{c}153 \times 132 \\
\text { x } 86 \mathrm{~cm} \\
(\text { anx alx } \\
\text { pro })\end{array}$ & $\begin{array}{c}220 \mathrm{~V} / 50 \\
\mathrm{~Hz}\end{array}$ \\
\hline $\begin{array}{c}\text { MT Freezer } \\
2.0 \text { by } \\
\text { Minitube }\end{array}$ & 1200 & 8,5 & $\begin{array}{r}112 \times 88 \\
\times 105 \mathrm{~cm}\end{array}$ & $\begin{array}{c}110 \mathrm{~V} / 60 \\
\mathrm{~Hz} \text { or } 230 \\
\mathrm{~V} / 50 \mathrm{~Hz}\end{array}$ \\
\hline $\begin{array}{c}\text { Micro- } \\
\text { Digicool } \\
\text { IMV }\end{array}$ & 240 & 8 & $\begin{array}{l}600 \times 380 \\
\times 520 \mathrm{~mm}\end{array}$ & $\begin{array}{c}220 \mathrm{~V} / 50 \mathrm{~Hz} \\
/ 6 \mathrm{~A}\end{array}$ \\
\hline $\begin{array}{c}\text { Freeze } \\
\text { control, } \\
\text { modelo CL- } \\
8800\end{array}$ & 23 & 1.5 & $\begin{array}{c}195 \times 225 \\
\times 90 \mathrm{~mm} \\
(\mathrm{WxDxH}) \\
\text { of the } \\
\text { controller }\end{array}$ & $\begin{array}{c}110- \\
220 \mathrm{~V} / 50- \\
60 \mathrm{~Hz}\end{array}$ \\
\hline $\begin{array}{c}\text { CRYOGEN } \\
\text { HSE } \\
\text { Portable } \\
\text { Freezer }\end{array}$ & 300 & 6 & $\begin{array}{c}\mathrm{C} 45,0 \mathrm{x} \\
\mathrm{L} 35,0 \mathrm{~cm} \\
\times \mathrm{A} 25,0\end{array}$ & $\begin{array}{c}127 \text { y } 220 \\
\operatorname{Vac}(50 \text { y } \\
60 \mathrm{~Hz})\end{array}$ \\
\hline $\begin{array}{c}\text { System } \\
\text { developed in } \\
\text { the present } \\
\text { investigation }\end{array}$ & 1028 & 6 & $\begin{array}{l}20 \text { L L2 } \\
\text { Tank }\end{array}$ & $\begin{array}{c}110- \\
220 \mathrm{~V} / 50- \\
60 \mathrm{~Hz}\end{array}$ \\
\hline
\end{tabular}

Table 4 shows that the commercial freezer that adapts to the needs of the region would be the CRYOGEN HSE Portable, since it has no drawbacks for the energy supply, with a capacity to freeze 300 straws.

For the reasons previously explained, we can assert that in our region, the manual application of the bovine semen freezing process will continue with less than optimal results due to the fact that the conditions for freezing are not the most ideal. Therefore, it is necessary to develop automatic systems of freezing bovine semen so that an autochthonous development with our own resources can take advantage of each of the equipment and elements available to us. This is the reason that led to the development of the automation and control system for the freezing of bovine semen, where a number of 1028 straws of $0.5 \mathrm{ml}$ can be frozen with an $\mathrm{LN}_{2}$ consumption of 6 liters per cycle from $5^{\circ} \mathrm{C}$ in approximately $13 \mathrm{~min}$.

Some modifications may be made to the system developed as shown in Figure 21 in order to eliminate the problem of 


\section{TECCIENCLA}

portability, since the use of the compressor results in this characteristic having a limited applicability.

The modified system will no longer have the 120-pound compressor, it will be replaced by a heat station in which the temperature of the air that enters the tank containing the liquid nitrogen $\left(\mathrm{LN}_{2}\right)$ will be controlled, and this thermal shock will generate more nitrogen gas with a lower inlet pressure.

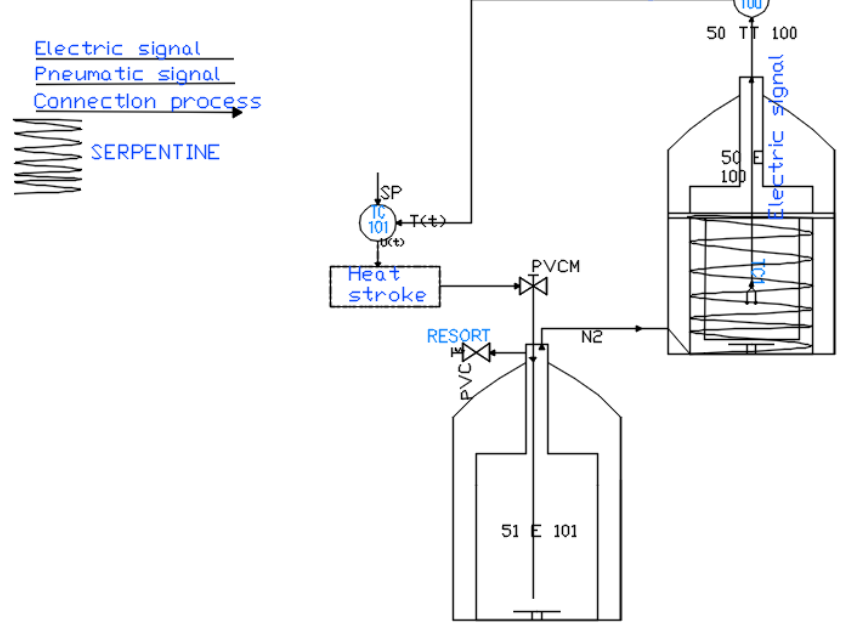

Figure 21. Modified system accounting for portability

\section{Conclusions}

In this applied research project, the aim of finding a better alternative that can carry out the process of freezing bovine semen by improving the rate of the freezing curve which leads to having a better quality frozen semen was achieved. The developed prototype took into account the stipulated freezing times so that the spermatozoa did not enter into a stress state due to the cooling speed with respect to the manual freezing process that is currently performed in the region and the processes that can be carried out by the previously analyzed commercial freezers. The use of liquid nitrogen was improved as the process could be carried out with an amount of 5 to 6 liters used to freeze 1028 straws. Previously used processes use 6 liters to temper the case where the manual process was carried out and considering the yield of the commercial freezers, in quantity of nitrogen versus quantity of straws, the developed prototype is better.

This project used materials and equipment that exist in the Agroempresarial SENA Aguachica center and Tecnoparque nodo Ocaña, which were part of the design and development of the system making this project accessible and efficient.

It is necessary to recognize that the system is subject to improvements in both design and technology. Just like it was mentioned in the discussion, the system can be adapted for other freezing curves for semen of different species of cattle and investigate with other types of diluents in order to generate longer or shorter stretches of time that may decrease the stress on the exposed spermatozoa [22].

\section{Acknowledgement}

The authors express their gratitude to God for the University of Pamplona, who provided the scientific support, to the Tecnoparque nodo Ocaña for its technical assistance and laboratory in the area of automation and industrial control, for the use of materials and equipment, the Agro-Business Center for its Technical advice in the biological area, welding and supply of materials.

\section{References}

[1] Hastuti, H., \& Suparman, S. (2016). The role of diluents in maintaining quality of bull sperm during freezing. Chalaza Journal of Animal Husbandry, (2 December), 58-64.

[2] Ahmed, M., Sinha, S., Deka, B. C., Biswas, R. K., \&Burhagohain, R. (2016). Effect of Rates of Freezing on Quality of Swamp Buffalo Semen Cryopreserved Using Programmable Freezer. Indian Vet. J, 93(08), 22-24.

[3] Cancino Aguirre, S.A. (2011). Comparación de la motilidad posdescongelado del semen de bovino criopreservado mediante la utilización de la técnica manual y automática con el diluyente comercial One Step (Doctoral dissertation): Universidad veracruzana. Veracruz México.

[4] Muiño, R., Peña, A. I., Rodríguez, A., Tamargo, C., \& Hidalgo, C. O. (2009). Effects of cryopreservation on the motile sperm subpopulations in semen from Asturiana de los Valles bulls. Theriogenology, 72(6), 860-868.

[5] Santos M. V., Sansinena, M. Zaritzky, N., \& Chirife J. (2013). How important are internal temperatura gradients in french straws during freezing of bovinesperm in nitrogen vapor? CryoLetters, 34(2), 158-165. Centro de Investigación y Desarrollo en Criotecnología de Alimentos (CONICET-UNLP) Buenos Aires, Argentina.

[6] Vallecillo, A. F. (2011). Caracterización reproductiva de toros de la raza marismeña como base a su conservación, (Doctoral dissertation, Universidad de Córdoba). España.

[7] Vishwanath, R., \& Shannon, P. (2000). Storage of bovine semen in liquid and frozen state. Animal ReproductionScience, 62(1), 2353.

[8] Amirat, L., Anton, M., Tainturier, D., Chatagnon, G., Battut, I., \&Courtens, J. L. (2005). Modifications of bull spermatozoa induced by three extenders: Biociphos, low density lipoprotein and Triladyl, before, during and after freezing and thawing. Reproduction, 129(4), 535-543

[9] Galabay, C. \& Efraín, J. (2000). Modernización a nivel de automatización del control de proceso en el área de dosificación y molienda de cemento, utilizando un PLC (Doctoral dissertation, Quito: EPN

[10] Ogata, K. (2003). Ingeniería de control moderna. Pearson Educación.

[11] Valentín Molina, Paola A. Molina, Horderlin V. Robles, Hermann Dávila, Luis J. Martínez (2015). Baseline correction in electrocardiographic signals using dynamic temporal sequence alignment, IFMBE Proceedings Volume 49, pp 528-5312014.

[12] López, M.E. (2002). Identificación de Sistemas. Aplicación al modelado de un motor de continua. UTPL, Loja. 
[13] Pinto, S. S., Mendoza, L. E., Velandia, H. J., Molina, V., \& Cervelon, L. J. (2015). Compressive Sensing Hardware in 1-D Signals. Tecciencia, 10(19), 5-10.

[14] Hamed, B. (2012). Design \& implementation of smart house control using LabVIEW. International Journal of Soft Computing and Engineering (IJSCE), 1(6), 2231-2307.

[15] Mojica, A. V. M., Sanz, M. B. C., Guerrero, L. J. M., \& Robles, H. (2016). Analysis through dynamic temporal sequence alignment in $\mathrm{SpO} 2$ signals. Tecciencia, 11(21), 39-43.

[16] Vizcaíno, J. R. L., \& Sebastiá, J. P. (2011). LabView: entorno gráfico de programación. Marcombo.

[17] Ang, K. H., Chong, G., \& Li, Y. (2005). PID control system analysis, design, and technology. IEEE transactionson control systemstechnology, 13(4), 559-576.

[18] Jiménez, L. M., Puerto, R., Reinoso, O., Fernández, C., \& Neco, R. (2005). RECOLAB: Laboratorio remoto de control utilizando Matlab y Simulink. Revista Iberoamericana de automática e informática industrial, 2(2), 64-72.

[19] Orozco, O. A., \& Ruiz, V. M. A. (2011). Sintonización de controladores PI y PID utilizando los criterios integrales IAE e ITAE. Journal of Tropical Engineering, 13(1-2).

[20] Wang, L. (2009). Model predictive control system design and implementation using MATLAB ${ }^{\circledR}$. Springer Science \& Business Media.

[21] DALAL, J., KUMAR, A., HONPARKHE, M., SINGHAL, S., \& SINGH, N (2016). Comparison of three programmable freezing protocols for the cryopreservation of buffalo bull semen. The Indian Journal of Animal Reproduction, 37(2).

[22] Stornelli, M. C., Tittarelli, C. M., Savignone, C. A., \&Stornelli, M. A. (2005). Efecto de los procesos de criopreservación sobre la fertilidad seminal. Analecta veterinaria, 25

[23] Muiño, R., Fernandez, M., \& Peña, A. I. (2007). Post-thaw Survival and Longevity of Bull Spermatozoa Frozen with an Egg Yolk-based or Two Egg Yolk-free Extenders after an Equilibration Period of $18 \mathrm{~h}$. Reproduction in domestic animals, 42(3), 305-311.

[24] Tvrdá, E., Halenár, M., Greifová, H., Mackovich, A., Hashim, F., \&Lukáč, N. (2016). The Effect of Curcumin on Cryopreserved Bovine Semen, International Journal of Biological, Biomolecular, Agricultural, Food and Biotechnological Engineering, 10 (11), 663-667.

[25] The imv technologies catalog Digitcool_en.pdf (2011) Programmable automatic freezers. France.

[26] Minitube Catálogo Bovino_Reproducción Animal_ES_2017.pdf. (2017). Tecnología de Reproducción Animal Bovina.

[27] The Biogenics catalog 2006. cryopreservation and life science instrument specialist. Napa California USA.

[28] Quintero, J. E., Manotas, G. F., Galeano, Y. A., \& Mauricio, D. (2014). Design and development of transcutaneous electrical stimulation equipment for neuromuscular rehabilitation in individuals with facial palsy. Tecciencia, 9(16), 43-49. 